\section{Foliar Boron Application Improves Flower Fertility and Fruit Set of Olive}

\author{
Slavko Perica, Patrick H. Brown ${ }^{1}$, Joseph H. Connell, \\ Agnes M.S. Nyomora, Christos Dordas, and Hening Hu \\ Department of Pomology, University of California, Davis, CA 95616
}

James Stangoulis

University of Adelaide, Waite Campus, Department of Plant Science, PMB 1, Glen Osmond, South Australia 5064

Additional index words. mineral nutrition, reproductive growth, flower morphology, Olea europaea

\begin{abstract}
A 2-year field study was conducted to determine if foliar B applications prior to flowering increased fruit set in olive (Olea europaea L.) cv. Manzanillo. Boron solutions were applied $\left(935 \mathrm{~L} \cdot \mathrm{ha}^{-1}\right)$ at four concentrations $\left(0,246,491\right.$, and $\left.737 \mathrm{mg} \cdot \mathrm{L}^{-1}\right)$ to trees exhibiting no vegetative symptoms of $B$ deficiency. Foliar $B$ application increased both the percentage of perfect flowers and fruit set, but no effect on pollen germination was observed in either year. The increase in fruit set was not accompanied by a reduction in fruit size. The beneficial effects of foliar $B$ application varied between years and were greater when fruit set was low. The results obtained here are in agreement with those observed in other tree species, in which foliar B applications made immediately prior to flowering or during the period of floral bud initiation significantly increased fruit set and yield. The physiological basis for this effect, however, remains unclear.
\end{abstract}

In California, the physiological process leading to olive flower differentiation in March and bloom in May starts in the preceding summer with flower induction (FernandezEscobar et al., 1992), followed by flower initiation in November (Martin, 1994; Pinney and Polito, 1990a). Olive produces either perfect flowers with pronounced green and functional pistils, or imperfect flowers that contain an aborted pistil and functional stamens (Brooks, 1948). The proportion of perfect flowers formed varies with inflorescence, cultivar, and prevailing environmental conditions.

A mature olive tree produces $\approx 500,000$ flowers (Martin, 1990), 10\% to $15 \%$ of which set fruit. This is followed by a rapid fruit drop that continues at a declining rate until 6-7 weeks after full bloom. In a year with normal flowering, $1 \%$ to $2 \%$ final fruit set will result in a good commercial yield (Griggs et al., 1975; Lavee, 1986).

The abscission of flowers and fruits is primary responsible for the small percentage of fruits retained to maturity (Rallo and Fernandez-Escobar, 1985; Uriu, 1959). The

Received for publication 8 June 2000. Accepted for publication 8 Nov. 2000. The work was supported by the U.S. Dept. of Agriculture (grant no. CSRS 9801010). We thank Katie Pinney and Vito S. Polito for advice on pollen techniques and use of their laboratory. The senior author acknowledges financial support from the Fulbright Program. The cost of publishing this paper was defrayed in part by the payment of page charges. Under postal regulations, this paper therefore must be hereby marked advertisement solely to indicate this fact.

${ }^{1}$ To whom requests for reprints should be addressed. E-mail address: phbrown@ucdavis.edu.

${ }^{2}$ Current address: Univ. of Adelaide, Waite Campus, Dept. of Plant Science, PMB 1, Glen Osmond, South Australia 5064. staminate flowers drop within 2 weeks after bloom (Cuevas et al., 1995), and many of the perfect flowers drop after varying periods of fruit development. Abscission affects mainly flowers in which the pistils are unable to reach a certain size, suggesting that competition for nutrient supply among developing fruits, or among the fruits and other active growing regions, plays a major role in abscission of perfect flowers (Cuevas et al., 1995; Rallo and Fernandez-Escobar, 1985; Rapoport and Rallo, 1991). A similar phenomenon has been observed in several fruit and nut species and has been attributed to boron (B) deficiency (Nyomora et al., 1997, 1999).

Although olive is well adapted to a wide range of growing conditions and soils, nutritional disorders caused by B deficiency are quite common (Demitriades et al., 1960; Klein and Lavee, 1977; Poly, 1986). The deficiency is usually described as abnormal fruit development, or "monkey face," and seems to be cultivar-dependent. Leaf-tip yellowing, shoot die-back, fruit drop, and bark abnormalities, in addition to death of the terminal bud that results in a "bushy" appearance, are common symptoms of B deficiency. In California, B deficiency has been reported in olive groves in Butte and Kern County (Freeman et al., 1994; Hartmann et al., 1980).

Existing leaf B standard values for the olive (Freeman et al., 1994) suggest an ade$\mathrm{mg} \cdot \mathrm{kg}^{-1}$. Within this range, tree response to foliar B has not been examined. The current critical values for olive are based solely on visual symptoms and we are unaware of any research that has established the critical $\mathrm{B}$ concentrations required for optimal yields in modern olive cultivars. Hartmann et al. (1980) reported that olive requires high $\mathrm{B}$, and $\mathrm{B}$ quate $\mathrm{B}$ concentration range from 19-150 fertilizers are frequently used in olive production, though mainly to control vegetative deficiencies. In olive, little is known about reproductive requirements for $\mathrm{B}$, the effect of $\mathrm{B}$ on flowering, fruit set or fruit abscission, or the response to foliar B applications.

Boron application increases fruit set and yield in several fruit and nut crops, including almond (Prunus dulcis Mill D.A. Webb), filbert (Corylus avellana L.), Italian prune (Prunus domestica L.), and sour cherry (Prunus cerasus L.) (Baron, 1973; Chaplin et al., 1977; Hanson, 1991; Nyomora et al., 1997; Shrestha et al., 1987). In many of these experiments, foliar B applications were effective in trees that showed no obvious vegetative symptoms of B deficiency. This suggests that there is a specific requirement for $\mathrm{B}$ in the reproductive process (Blevins and Lukaszewski, 1998; Dell and Huang, 1997).

Given the importance of B for fruit set in many tree species, the relatively high $\mathrm{B}$ demand of olive, and the occurrence of B deficiency in Californian orchards, we hypothesized that foliar B application would increase fruit set and hence yield of olive. The objective of this study was to investigate the effect of spring foliar B application on flower development, pollen germination, fruit set, and yield of olive.

\section{Materials and Methods}

In 1997, a bearing olive orchard, cv. Manzanillo, with July tissue B concentration of $17 \mathrm{mg} \cdot \mathrm{kg}^{-1}$, was selected near Oroville (Butte County), Calif. Experiments were conducted in both 1998 and 1999. Planting density was 370 trees/ha. Boron as Solubor $\left(\mathrm{Na}_{2} \mathrm{~B}_{8} \mathrm{O}_{13} \cdot 4 \mathrm{H}_{2} \mathrm{O}\right.$; U.S. Borax, Valencia, Calif.), containing $20.5 \% \mathrm{~B}$, was applied with a tractor-mounted sprayer at four concentrations $(0$, 246, 491, and $737 \mathrm{mg} \cdot \mathrm{L}^{-1} \mathrm{~B}$ ) in $935 \mathrm{~L} \cdot \mathrm{ha}^{-1}$ of water. Boron was applied $\approx 3$ weeks before anthesis (21 Apr. 1998 and 1 May 1999). The four treatments were applied to the same trees each year and imposed in a randomized block design with five trees per plot and six replications (a total of 120 experimental trees). Single border trees separated the treatments and minimized cross-treatment contamination.

In vitro pollen germination. Pollen germination was tested in vitro as described by Pinney and Polito (1990b), with or without the addition of boric acid $\left(10 \mathrm{mg} \cdot \mathrm{L}^{-1}\right)$ in the germination medium. Germination, evaluated after $24 \mathrm{~h}$ at $24^{\circ} \mathrm{C}$, was rated as nongerminated if tube length was less than four times the diameter of the grain, and germinated if it exceeded four times the diameter of the grain. Germination percentage was based on 100 pollen grains from each of six replicates.

Flowering, fruit set, fruit size, and yield measurement. On each replicate tree, five (1998) or 20 (1999) shoots, uniform in length and exposure, with full floral differentiation $(>95 \%)$, were selected $\approx 4$ weeks before anthesis and tagged a few nodes above the base. In 1998, all flowers on each tagged shoot were counted; in 1999, only the total number of inflorescences were counted. 
For fruit set determination, fruits remaining on the shoots were counted on 10 consecutive inflorescences above the tagged point, and on five consecutive nodes. Fruit set was determined as the percentage of fruit remaining, based either on total flower count (1998), or as the average number of flowers on 150 inflorescences within a replicate (900 inflorescences per treatment) on 14 May 1999. In 1999, a total of 6000 inflorescences (10 inflorescence per shoot $\times 600$ shoots) were counted per treatment.

At anthesis (10 May 1998 and 18-22 May 1999), five uniform shoots per tree were detached and taken to the laboratory where the numbers of perfect and imperfect flowers on a single inflorescence, arbitrarily chosen from the fourth node from the base of each detached shoot, were recorded. "Perfect flower" in this report is defined as a flower that has fully developed stamens, pistil, calyx, and petals, while a flower with any organs missing is defined as "imperfect."

In 1998 each individual tree was harvested manually, and yield and fruit size distribution were determined. In 1999, fruit set was determined from 7-13 Sept. and random fruit samples were taken for fruit size determination on 12 Nov. just before commercial harvest. Fruit size was determined according to commercial 'Manzanillo' olive grades (Sibbett et al., 1986). Because of excessive tree yield and, consequently, small fruit size in 1999, trees were shaken mechanically and yield was not recorded.

Boron analysis. For B analysis, a total of 100 leaves (20/tree from the mid-shoot) were collected from each plot in 10 May 1998 and 22 May 1999. Leaves were washed for $1 \mathrm{~min}$. in deionized water, dried at $70{ }^{\circ} \mathrm{C}$ for $72 \mathrm{~h}$, and ground to pass a 30 -mesh screen. Flowers and pollen were collected from five shoots per tree. All the samples were ashed at $500{ }^{\circ} \mathrm{C}$ for $4 \mathrm{~h}$, and the ash was dissolved in $10 \mathrm{~mL} 1 \mathrm{~N}$ $\mathrm{HNO}_{3}$ and heated to $90{ }^{\circ} \mathrm{C}$ for $25 \mathrm{~min}$. Boron concentration in the samples was determined using inductively coupled plasma-mass spectrometry (ICP-MS, Sciex Elan 500; Perkin Elmer Corp., San Jose, Calif.) as described previously (Brown and $\mathrm{Hu}, 1994)$. Data are presented as means with SE.

\section{Results}

Effect of B application on tissue B concentration. In early March of both years, leaf B concentration was $\approx 16 \mathrm{mg} \cdot \mathrm{kg}^{-1}$ dry weight. Foliar B application significantly increased B concentration in leaves sampled 3 weeks after treatment (Table 1). However, the amount of increase varied from year to year. For example, leaf B increased only slightly in 1998, but dramatically in 1999, when the highest B application increased leaf $\mathrm{B}$ concentration $\approx 80 \%$. A significantly greater and almost linear increase in tissue $\mathrm{B}$ concentration was observed in the flowering organs (Table 1).

Effect of $B$ application on in vitro pollen germination. Boron influences in vitro pollen germination and growth and is commonly added to germination media. In no instance did foliar B treatment affect pollen germination, although addition of $10 \mathrm{mg} \cdot \mathrm{L}^{-1}$ boric acid in the medium improved it (data not shown).

Effect of $B$ application on flowering and fruit set. In 1998, the percentage of perfect flowers was lowest in the control, and increased significantly with increasing B rates up to $491 \mathrm{mg} \cdot \mathrm{L}^{-1} \mathrm{~B}$ (Table 1 ), a maximum increase of $49 \%$ being obtained. However, a further increase to $737 \mathrm{mg} \cdot \mathrm{L}^{-1}$ did not increase response. Consistent with the results from 1998, B application in 1999 increased the percentage of perfect flowers; the maximum effect was obtained at $246 \mathrm{mg} \cdot \mathrm{L}^{-1} \mathrm{~B}$, which increased the percentage by $22 \%$.

In 1998, fruit set in June was increased by $43 \%$ to $54 \%$ by response to all B applications (Table 1). In 1999, all B treatments increased fruit set in both June (6.7\% to $9.1 \%$ higher than the control) and September (10\% to $11 \%$ above the control).

Effect of $B$ application on fruit size and final yield. In 1998, a light bearing year with an average yield of $12 \mathrm{~kg}$ per tree, the application of $246 \mathrm{mg} \cdot \mathrm{L}^{-1} \mathrm{~B}$ increased yield $30 \%$. However, higher B concentrations (491 and 737 $\mathrm{mg} \cdot \mathrm{L}^{-1} \mathrm{~B}$ ) only increased yield $6 \%$ and $1 \%$, respectively. In 1998, fruit size distribution in each category remained unchanged regardless of B treatment (data not shown). In 1999, a heavy bearing year with an estimated yield 3 to 5-fold higher than in 1998, fruit size was also unaffected by B treatments. The size distribution, however, was shifted downward in comparison with 1998, and fruit maturation was unusually late. In 1998 most of the fruits $(73 \%$ to $76 \%$ ) were in either the "Extra large" or "Large" category, while in 1999, most (67\% to $82 \%$ ) were in the "Standard," "Petite," or "Subpetite" categories (data not shown).

\section{Discussion}

The average leaf B concentration in control trees $\left(16 \mathrm{mg} \cdot \mathrm{kg}^{-1}\right.$ in March, $17 \mathrm{mg} \cdot \mathrm{kg}^{-1}$ in July) was slightly below the currently recognized adequate level of $19 \mathrm{mg} \cdot \mathrm{kg}^{-1}$ (Freeman et al., 1994). Boron concentrations in flowers and pollen grains were generally much higher than those in the leaves. This is consistent with the suggestion that the $B$ requirement is higher for reproductive than for vegetative growth, or that reproductive organs simply accumulate more B (Blevins and Lukaszewski, 1998; Dell and Huang, 1997). In several species, the higher concentration of, and requirement for, B in flowering tissue, particularly for pollen development and growth as opposed to vegetative growth, is well documented (Dell and Huang, 1997; Hanson et al., 1985; Peter and Stanley, 1974; Stanley and Linskens, 1974).

Boron concentrations in the flowers and pollen grains increased in proportion to the $\mathrm{B}$ concentration applied. The effect of B application was also much more consistent in reproductive than in leaf tissue. These results agree with findings on other fruit and nut crops in which B concentration of reproductive tissues, buds, flowers or fruits is highly responsive to B application (Hanson, 1991; Nyomora at al., 1997, 1999). In this experiment, the buds were already swollen when B was applied. Thus, the increased B concentration could be related to direct uptake by the reproductive tissue following treatment. Significant translocation from treated leaves to flowers may also occur, since Delgado et al. (1994) suggested that B is mobilized from young olive leaves during anthesis to supply the needs of flowers and fruits. Brown and $\mathrm{Hu}$ (1998) also showed that phloem retranslocation of B occurs in olive. This has been confirmed using foliar-applied ${ }^{10} \mathrm{~B}$, which significantly enriched the developing olive flowers, fruits, and growing shoots (Perica et al., 2001). Since mannitol is a primary transport carbohydrate in olive (Drossopoulos and Niavis, 1988; Perica et al., 2001), co-movement of a B-mannitol complex probably occurs in olive, as has been demonstrated for celery (Apium graveolens L.) (Hu et al., 1997).

Boron definitely influences in vivo and in vitro pollen germination and growth (Blevins and Lukaszewski, 1998). In our experiment foliar B application to field trees did not enhance in vitro germination. However, addition of $1.75 \mathrm{mg} \cdot \mathrm{L}^{-1} \mathrm{~B}\left(10 \mathrm{mg} \cdot \mathrm{L}^{-1}\right.$ of boric acid) to the germination medium significantly increased germination of pollen from all treatments. The results suggest that the pollen grains may contain adequate $\mathrm{B}$ to germinate

Table 1. Effects of applying foliar sprays of B to 'Manzanillo' olive trees 3 weeks before anthesis on tissue B concentration, percentage of perfect flowers, and fruit set, 1998-99.

\begin{tabular}{|c|c|c|c|c|c|}
\hline \multirow[b]{2}{*}{ Year } & \multirow[b]{2}{*}{ Tissue or time } & \multicolumn{4}{|c|}{ Rate of B application $\left(\mathrm{mg} \cdot \mathrm{L}^{-1}\right)$} \\
\hline & & 0 & 246 & 491 & 737 \\
\hline \multicolumn{6}{|c|}{ Tissue B concentration ${ }^{2}\left(\mathrm{mg} \cdot \mathrm{kg}^{-1} \mathrm{DW}\right)$} \\
\hline \multirow{2}{*}{1998} & Leaf & $16.5 \pm 0.4^{y}$ & $19.1 \pm 0.5$ & $19.8 \pm 0.7$ & $19.9 \pm 0.4$ \\
\hline & Flower & $35 \pm 2$ & $48 \pm 4$ & $55 \pm 3$ & $65 \pm 4$ \\
\hline \multirow[t]{2}{*}{1999} & Leaf & $30 \pm 1$ & $36 \pm 2$ & $44 \pm 2$ & $53 \pm 5$ \\
\hline & Pollen & $68 \pm 1$ & $124 \pm 3$ & $190 \pm 4$ & $252 \pm 7$ \\
\hline \multicolumn{6}{|c|}{ Perfect flowers at anthesis (\%) } \\
\hline 1998 & May & $45 \pm 4$ & $65 \pm 4$ & $67 \pm 3$ & $52 \pm 5$ \\
\hline 1999 & May & $51 \pm 2$ & $62 \pm 2$ & $60 \pm 3$ & $53 \pm 3$ \\
\hline \multicolumn{6}{|c|}{ Fruit set (\%) } \\
\hline 1998 & June & $2.37 \pm 0.26$ & $3.46 \pm 0.24$ & $3.37 \pm 0.36$ & $3.63 \pm 0.41$ \\
\hline \multirow[t]{2}{*}{1999} & June & $6.71 \pm 0.14$ & $7.16 \pm 0.10$ & $7.32 \pm 0.11$ & $7.26 \pm 0.09$ \\
\hline & Sept. & $3.87 \pm 0.07$ & $4.26 \pm 0.08$ & $4.40 \pm 0.08$ & $4.31 \pm 0.09$ \\
\hline
\end{tabular}

${ }^{2}$ Samples collected at anthesis (10 May 1998; 22 May 1999).

\footnotetext{
${ }^{\mathrm{y}} \mathrm{Mean} \pm \mathrm{SE}$.
} 
normally, but not enough to maintain pollen tube growth.

Boron rates of 246 and $491 \mathrm{mg} \cdot \mathrm{L}^{-1}$ were effective in increasing the percentage of perfect flowers, while the highest B concentration tested $\left(737 \mathrm{mg} \cdot \mathrm{L}^{-1}\right)$ was less so. The effect of $B$ on fruit set, however, did not exactly parallel its effect on the formation of perfect vs. imperfect flowers. For example, all of the B treatments applied increased fruit set significantly, with the increase ranging from $6.7 \%$ to $9.1 \%$ (June) or $10 \%$ to $11 \%$ (Sept.) in the "on" year, to $43 \%$ to $54 \%$ in the "off" year. In comparison, B increased the number of perfect flowers by $22 \%$ to $49 \%$ in both years when applied at 246 or $491 \mathrm{mg} \cdot \mathrm{L}^{-1}$. The significantly greater effect of B on flower formation than on final set or yield suggests that a dilution effect may have occurred and that the optimum concentration during flowering may not be maintained as fruits grow. Alternatively, fruit set may not be correlated with the number of perfect flowers.

In the "off" year, application of $246 \mathrm{mg} \cdot \mathrm{L}^{-1}$ $B$ was more effective in increasing yield than were higher concentrations $\left(491,737 \mathrm{mg} \cdot \mathrm{L}^{-1}\right.$ B). In both years, the increase in yield or fruit set resulting from B application $(>30 \%)$ did not reduce fruit size. Increased fruit set and yield following B application have been reported for several fruit and nut crops, including almond (Nyomora et al., 1997, 1999), filberts (Baron, 1973), Italian prunes (Chaplin et al., 1977), and sour cherry (Hanson, 1991). Interestingly, the concentrations of B that resulted in additional yield were remarkably similar $\left(200-400 \mathrm{mg} \cdot \mathrm{L}^{-1}\right)$ in all studies, whereas in almond application of $\mathrm{B}$ at $>400 \mathrm{mg} \cdot \mathrm{L}^{-1}$ had no significant effect on set or yield.

Fruit size in olive is inversely correlated with yield (Hartmann, 1952; Lavee and Spiegel-Roy, 1967). Our findings that increases of $13 \%$ and $30 \%$ in yield did not effect fruit size may reflect the increased photosynthetic capacity or improved sink-strength of the remaining fruit.

In summary, the response of olive to foliar $B$ application was significant in both years and was more pronounced when fruit set was low than when it was high. The effect of B on yield can be attributed to both an increased percentage of perfect flowers and to an apparent, although poorly understood, effect on fruit retention. A multi-factor benefit of foliar B applications has also been observed in almond, where B applications to male and female floral organs independently and additively improve yield (Nyomora et al., 1997, 1999). The mode of action of foliar B on yield is poorly understood.

\section{Literature Cited}

Baron, L.C. 1973. The value of boron sprays on filberts. Nut Growers Soc. Oregon-Washington 58:22-28.

Blevins, D.G. and K.M. Lukaszewski. 1998. Boron in plant structure and function. Annu. Rev. Plant Physiol. Plant Mol. Biol. 49:481-500.

Brooks, R.M. 1948. Seasonal incidences of perfect and staminate olive flowers. Proc. Amer. Soc. Hort. Sci. 52:213-218.

Brown, P.H. and H. Hu. 1994. Boron uptake by sunflower, squash and cultured tobacco cells. Physiol. Plant. 91:435-441.

Brown, P.H. and H. Hu. 1998. Phloem boron mobility in diverse plant species. Bot. Acta 111:331335.

Chaplin, M.H., R.L. Stebbins, and M.N. Westwood. 1977. Effect of fall-applied boron sprays on fruit set and yield of 'Italian' prune. HortScience 12:500-501.

Cuevas, J., H.F. Rapoport, and L. Rallo. 1995. Relationships among reproductive processes and fruitlet abscission in 'Arbequina' olive. Adv. Hort. Sci. 9:92-96.

Delgado, A., M. Benlloch, and R. FernandezEscobar. 1994. Mobilization of boron in olive trees during flowering and fruit development. HortScience 29:616-618.

Dell, B. and L. Huang. 1997. Physiological response of plants to low boron. Plant Soil 193:103-120.

Demitriades, S.D., N.A. Gavalas, and C.D. Holevas. 1960. Boron deficiency in olive groves of Lesbos island. Ann. Inst. Phitopathol. Benaki. 3:119129.

Drossopoulos, J.B. and C.A. Niavis. 1988. Seasonal changes of the metabolites in the leaves, bark and xylem tissues of the olive tree (Olea europaea L). II. Carbohydrates. Ann. Bot. 62:321-327.

Freeman, M., K. Uriu, and H.T. Hartmann. 1994. Diagnosing and correcting nutrient problems, p. 77-86. In: L. Ferguson, G.S. Sibbett and G.C. Martin (eds.). Olive production manual. Univ. Calif., Div. Agr. and Natural Resources, Publ. 3353.

Fernandez-Escobar, R., M. Benlloch, C. Navarro, and G.C. Martin. 1992. The time of floral induction in the olive. J. Amer. Soc. Hort. Sci. 117:304 307.

Griggs, W.H., H.T. Hartmann, M.V. Bradley, B.T. Iwakiri, and J.E. Whisler. 1975. Olive pollination in California. California Agr. Expt. Sta. Bul. No. 869.

Hanson, E.J. 1991. Sour cherry trees respond to foliar boron applications. HortScience 26:11421145.

Hanson, E.J., M.H. Chaplin, and P.J. Breen. 1985. Movement of foliar applied boron out of leaves and accumulation in flower buds and flower parts of 'Italian' prune. HortScience 20:747748.

Hartmann, H.T. 1952. Spray thinning of olives. Calif. Agr. 6:7.

Hartmann, H.T., K.W. Opitz, and J.W. Beutel. 1980. Olive production in California. Univ. Calif. Leaflet 2474.
Hu, H., S.G. Penn, C.B. Lebrilla, and P.H. Brown. 1997. Isolation and characterization of soluble boron complexes in higher plants. Plant Physiol. 113:649-655.

Klein, I. and S. Lavee. 1977. The effect of nitrogen and potassium fertilizers on olive production. Fertilizer use and production of carbohydrates and lipids, p. 295-304. In: Proc. 13th Colloq. Intl. Potash Inst. Atlanta.

Lavee, S. 1986. Olive. In: Monselise S.P. (ed.). CRC handbook of fruit set and development. CRC Press, Boca Raton, Fla.

Lavee, S. and P. Spiegel-Roy. 1967. The effect of time of application of two growth substances on the thinning of olive fruits. J. Amer. Soc. Hort. Sci. 91:180-186.

Martin, G.C. 1990. Olive flowers and fruit population dynamics. Acta Hort. 286:141-153.

Martin, C.G. 1994. Botany of the olive. In: L. Ferguson, G.S. Sibbett and G.C. Martin (eds.). Olive production manual. Univ. Calif., Div. Agr. and Natural Resources Publ. 3353.

Nyomora, A.M.S., P.H. Brown, and M. Freeman. 1997. Fall foliar-applied boron increases tissue boron concentration and nut set of almond. J. Amer. Soc. Hort. Sci. 122:405-410.

Nyomora, A.M.S., P.H. Brown, and B. Krueger. 1999. Rate and time of boron application increase almond productivity and tissue boron concentration. HortScience 34:242-245.

Perica, S., N. Bellaloui, C. Greve, H. Hu, and P.H. Brown. 2001. Boron transport and soluble carbohydrate concentrations in olive. J. Amer.Soc. Hort Sci. 126:291-296.

Peter, J.K. and R.G. Stanley. 1974. Boron in pollen and pollen cell fractions, p. 131-136. In: R.G. Stanley and H.G. Linskens (eds.). Pollen: Biochemistry and management. Springer, Berlin.

Pinney, K. and V.S. Polito 1990a. Flower initiation in 'Manzanillo' olive. Acta Hort. 286:203-205.

Pinney, K. and V.S. Polito. 1990b. Olive pollen storage and in vitro germination. Acta Hort. 286:207-210.

Poly, M. 1986. The olive's alternating production pattern. Olivae 10:11-33.

Rallo, L. and R. Fernandez-Escobar. 1985. Influence of cultivar and flower thinning within the inflorescence on competition among olive fruit. J. Amer. Soc. Hort. Sci. 110:303-308.

Rapoport, H.F. and L. Rallo. 1991. Fruit set and enlargement in fertilized and unfertilized olive ovaries. HortScience 26:896-898.

Shrestha, G.H., M.M. Thompson, and T.L. Righetti. 1987. Foliar applied B increases fruit set in 'Barcelona' hazelnut. J. Amer. Soc. Hort. Sci. 112:412-416.

Sibbett, G.S., L. Ferguson, D. Anderson, M.W. Freeman, and G. Welch. 1986. Timing Manzanillo olive harvest for maximum profit. Calif. Agr. 40:19-22.

Stanley, R.G. and H.F. Linskens. 1974. Boron in pollen and floral organs, p. 307-309. In: R.G. Stanley and H.G. Linskens (eds.). Pollen: Biochemistry and management. Springer, Berlin.

Uriu, K. 1959. Periods of pistil abortion in the development of the olive flower. Proc. Amer. Soc. Hort. Sci. 73:194-202. 